
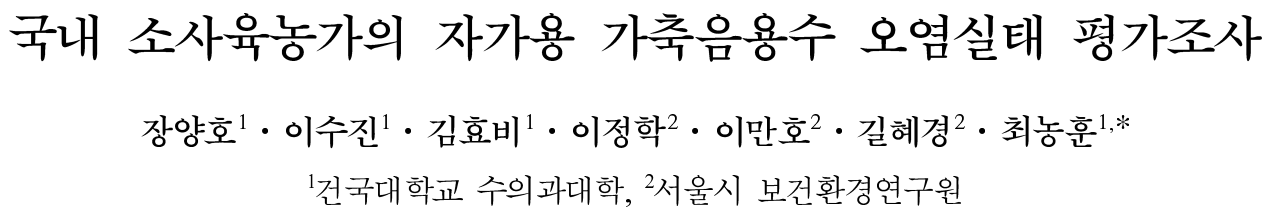

(게재승인: 2011년 1월 6일)

\title{
Contamination status of groundwater used as livestock drinking in beef and dairy cattle farms, Korea
}

\author{
Yangho Jang ${ }^{1}$, Soojin Lee ${ }^{1}$, Hyobi Kim¹, Jeonghak Lee ${ }^{2}$, Manho Lee ${ }^{2}$, Hyekyoung Gil ${ }^{2}$, Nonghoon Choe ${ }^{1, *}$ \\ ${ }^{1}$ College of Veterinary Medicine, Konkuk University, Seoul 143-701, Korea \\ ${ }^{2}$ Seoul Research Institute of Public Health and Environment, Seoul 137-734, Korea
}

(Accepted: January 06, 2011)

\begin{abstract}
In Korea, groundwater is main water source in livestock farms. Most dairy and cattle farms have constructed their own wells for human drinking and livestock farming. However, these private residential wells have not been controlled by government and also there was scant study about livestock drinking water quality. Therefore this study was to monitor of the livestock farms' groundwater quality in Korea. Water samples were collected at 123 dairy and cattle farms and were analysed forty six substances with quality standard for drinking water approved by the Minister of Environment. Seventy eight (63.4\%) of 123 samples failed to drinking water stand a test. The most frequent contaminants were nitrate-nitrogen and microbial. $22.8 \%(n=28)$ of samples showed nitrate- $\mathrm{N}$ concentration of higher than $10 \mathrm{mg} / \mathrm{L}$ meant that can't be used drinking water for human and the Nitrate-N concentration analysed in the range of 0.2 to $61.2 \mathrm{mg} / \mathrm{L}$. All of 78 failed to drinking samples had microbial problems, especially $5.7 \%(\mathrm{n}=7)$ of samples indicated water could be contaminated by feces. Other contaminants detected were zinc and evaporation residue. Especially detected zinc concentration $(32 \mathrm{mg} / \mathrm{L})$ was about ten times higher than standard of zinc $(3 \mathrm{mg} / \mathrm{L})$. Regression analysis indicated that groundwater $\mathrm{pH}$ did not influence to nitrate$\mathrm{N}$ concentration but the hardness and chloride could affect to nitrate- $\mathrm{N}$ concentration in the groundwater. Most livestock farms were adjacent to crop farmland in Korea. This could cause contamination of groundwater with nitrate-N and pesticide that could accumulate livestock product. Moreover Heavy metal such as zinc and copper could be released from a corrosive plated water pipe in livestock farm. Put together, Korea livestock system is indoor, not pasture-based, hence livestock could be exposed to potential contaminated water consistently. Therefore on the basis of these data, appropriate livestock drinking water quality standards should be prepared to keep livestock healthy and their product safe. Further, livestock drinking water quality should be monitored continuously in suitable livestock drinking water standards.
\end{abstract}

Keywords : groundwater contamination, livestock drinking water quality, microbial contamination, $\mathrm{NO}_{3}-\mathrm{N}$

\section{서 론}

우리나라의 소 사양 체계는 대부분 축사사육을 하고 있으며 가축의 음용수는 일반적으로 농장에서 자체 개 발한 지하수를 이용하고 있다. 그러나 국내 축산농가의
자가용 지하수 수질은 수질측정망 부족 및 측정시설의 부재로 전국적인 오염실태의 파악이 곤란한 상황이다 [2]. 지하수를 오염시키는 원인 물질로는 산업 - 농업 폐 기물(살충제와 제초제 등)과 가축 사육 농가에서 발생하 는 폐기물(가축분뇨) 등이 있다. 가축의 배설물은 미생

\footnotetext{
*Corresponding author

Tel: +82-2-450-3709, Fax: +82-2-454-3709

E-mail: nojamaji@hanmail.net
} 
물학적 오염의 원인으로 작용하며, 분뇨의 단백질 성분 이 물에 가수분해되면 암모니아성 질소가 생성되며 이 것이 아질산성질소(nitrite-N), 질산성질소(nitrate-N)로 순 차적으로 변하게 된다. 이와 함께 농업에 사용한 질소비 료에 의해 생성된 질산성질소가 약 $80 \%$ 지하수 오염의 원인이 되고 있다 [17]. 이외에 일부 살충제와 제초제들 도 지하수로 유입될 수 있는데 그 성상에 따라 물을 섭 취하는 동물의 지방과 근육조직에 축적되어 전체적인 food chain을 오염시킬 수 있다 $[15,24,25,28]$. 현재까 지 오염된 물을 지속적으로 섭취하는 가축의 경우, 그 생산물에 어떠한 영향을 미치는지는 밝혀진 바가 없으 나 가축의 사료와 사람이 섭취하는 조리된 음식에서 유 기염소제 등의 살충제 검출이 꾸준히 보고되고 있다 [11, $15,20,21,24,27]$. 이와 같은 이유로 우리나라에서도 식육과 그 부산물에서 농약의 잔류기준을 법적으로 정 해놓고 있다 [3].

가축음용수의 질에 대한 연구들은 주로 음용수의 화 학적 조건들이 가축의 생산성에 미치는 영향에 초점이 맞춰졌으며 $[7,9,22,23]$, 가축의 건강과 안전한 축산 물 생산을 위한 가축음용수질 기준에 관한 연구들은 거 의 수행되지 않았고, 가축음용수 기준이 법적으로 고시 되어 있는 나라도 없다. 다만, 미국의 경우 2001년 National Research Council에서 발간한 자료에 가축 음용 수에 대한 전반적인 기준을 정한 바 있는데 염도, 경도, 질산성질소, 황산이온, $\mathrm{pH}$, 각종 미량원소(알루미늄, 비 소, 붕소, 카드뮴, 코발트, 구리, 불소, 납, 망간, 수은, 니 켈, 셀레늄, 크롬, 바나듐), 총대장균군에 대한 기준을 권 고사항으로 정해놓고 있다 $[5,26]$. 그러나 우리나라에 는 권고사항으로 고시된 가축 음용수 기준이 없으며 사 적으로 개발한 지하수에 대한 정부차원의 수질검사가 실시된 적이 없고 수질관리도 미약하기 때문에 가축 음 용수의 안전을 보장할 수 없는 실정이다.

국내의 가축사육농가들은 과수원이나 논 - 밭과 같은 경작지와 인접해 있는 경우가 많고, 중금속으로 도금된 낡은 급수 파이프를 그대로 사용하는 농가도 많다. 이와 함께 자연방목을 하는 외국과 달리 대부분의 국내 가축 사육농가는 축사 사육을 하고 있는데 이러한 사육형태 는 검증되지 않은 물을 지속적으로 섭취하게 되어 잠재 적인 위험인자로 작용할 수 있다. 그러므로 가축의 건 강 유지와 나아가 안전한 축산물의 생산을 위해서 국 내 실정에 적용할 수 있는 가축음용수 기준의 제정이 절실하다.

본 연구는 경상남도를 제외한 전국 123 곳 소사육 농 가를 대상으로 가축 음용수를 채수하여 환경부령 제 377 조 먹는물 수질기준 및 검사등에 관한 규칙에 따라 총 46항목에 대한 분석을 실시하여 가축 음용수의 오염실
Table 1. Sampling regions and each sample number

\begin{tabular}{crr}
\hline \hline \multirow{2}{*}{ Location } & \multicolumn{2}{c}{ Year } \\
\cline { 2 - 3 } & 2008 & 2009 \\
\hline Gyeonggi & 10 & 13 \\
Gangwon & 2 & 5 \\
Chungbuk & 2 & 34 \\
Chungnam & 13 & 1 \\
Jeonbuk & 0 & 1 \\
Jeonnam & 0 & 16 \\
Gyeongbuk & 15 & 11 \\
\hline Total No. of Samples & 42 & 81
\end{tabular}

태를 파악해보고자 하였다.

\section{재료 및 방법}

\section{채수지역, 방법 및 기간}

경상남도와 제주도를 제외한 전국의 7 개도에서 123 곳 의 소사육농가(Table 1)에서 가축음용수로 자체 개발한 지하수를 $4 \mathrm{~L}$ 멸균 채수통에 채수하여 $4^{\circ} \mathrm{C}$ 를 유지한 상 태로 운송하였다. 지하수의 채취는 2008 2009년 7 8월 사이, 우천 시 일주일 후 채수를 기준으로 시행하였다.

\section{분석방법 및 항목}

물의 분석은 먹는물공정시험기준(2008년)과 수질오염 공정시험기준(환경부고시 제2008-99호)에 따라 분석하 였으며 분석 항목 및 방법은 Table 2 와 같다.

\section{결 과}

총 123 개의 시료를 먹는물 기준으로 검사한 결과 78 개(약 $63.4 \%$ )의 시료가 부적합 판정을 받았다. 부적합 시료의 항목별 결과를 보면 크게 질산성 질소와 미생물 의 오염으로 나눌 수 있었다(Fig. 1).

가장 높은 빈도를 보인 부적합 항목은 일반세균과 총 대장균군이 함께 초과된 경우로 78 개 시료 중 16 개가 해당되었다. 질산성질소와 미생물학적 오염을 함께 보 인 시료는 16 개였으며, 이 중 분변에 오염을 시사하는 분원성 세균이 검출된 시료는 1 건이었으며, 질산성질소 초과 검출없이 분원성 세균이 검출된 시료는 4 건으로 총 5 건의 시료는 분변에 의해 지하수가 오염되었음을 확인할 수 있었다. 총대장균군과 분원성세균의 검사는 시험관 내 Durham 시험관이 들어있는 시험관에 기체발 생이 관찰되었을 때 확정시험을 실시하여 최종판단하였 으며, 미생물의 종류를 확인하는 세부적인 실험은 진행 하지 않았다. 이외에 기준치 이상으로 검출된 항목은 아 
Table 2. Analytical methods and instruments for each item

\begin{tabular}{|c|c|c|}
\hline & Substance & Analytical methods \& Instruments \\
\hline \multirow[b]{2}{*}{ Microbial } & Aerobic plate count & Plate Count Method \\
\hline & $\begin{array}{l}\text { Total coliforms } \\
\text { Fecal coliforms }\end{array}$ & Multiple Tube Fermentation Method \\
\hline \multirow{5}{*}{$\begin{array}{l}\text { Inorganic } \\
\text { Matter }\end{array}$} & Fluorine, NO-N & Ionchromatography \\
\hline & Chloride, Sulfate & (DX-500; Dionex,USA) \\
\hline & NH-N, Cyanide & Spectromatography \\
\hline & Aluminium & (HP UV 8453A; Hewlett Packard, USA) \\
\hline & $\begin{array}{l}\text { Mercury, Chromium } \\
\text { Arsenic, Lead, Boron } \\
\text { Cadmium, Selenium } \\
\text { Copper, Zinc ,Iron } \\
\text { Manganese }\end{array}$ & $\begin{array}{l}\text { Atomic Absorption Spectrophotometer } \\
\text { (Hitachi Z-8100; Hitachi, Japan) } \\
\text { Atomic Emission spectrometer } \\
\text { (high disperson ICP; Teledyne Leeman Labs, USA) }\end{array}$ \\
\hline \multirow[b]{3}{*}{$\begin{array}{l}\text { Organic } \\
\text { Matter }\end{array}$} & Phenols & $\begin{array}{l}\text { Spectrophotometer method } \\
\text { (HP UV 8453A; Hewlett Packard, USA) }\end{array}$ \\
\hline & $\begin{array}{l}\text { Parathion, Diazinon } \\
\text { Trichloroethylene } \\
\text { Fenitrothion, Carbaryl }\end{array}$ & $\begin{array}{l}\text { Gas Chromatography } \\
\text { (Young Lin M600D; Young Lin Tech, Korea) }\end{array}$ \\
\hline & $\begin{array}{l}\text { Dichloromethane } \\
\text { Carbon tetrachloride } \\
\text { 1,1-dichloroethylene1,1,1-Trichloroethane } \\
\text { 1,2-Dibromo } \\
\text {-3-Chloropropane } \\
\text { Tetrachloroethylene } \\
\text { Benzene } \\
\text { Toluene } \\
\text { Ethylbenzene } \\
\text { Xylene }\end{array}$ & $\begin{array}{l}\text { Gas Chromatography Purge \& Trap } \\
\text { (Finigan 9001; ThermoQuest, USA) }\end{array}$ \\
\hline \multirow{5}{*}{$\begin{array}{l}\text { Aesthetic } \\
\text { Matter }\end{array}$} & $\mathrm{pH}$ & $\mathrm{pH}$ meter \\
\hline & $\begin{array}{l}\text { Permanganate value } \\
\text { Hardness }\end{array}$ & Titration method \\
\hline & Odor \& Taste & Taste method \\
\hline & Color \& Turbidity & Visual comparison \\
\hline & Total dissolved solids & Weight method \\
\hline
\end{tabular}

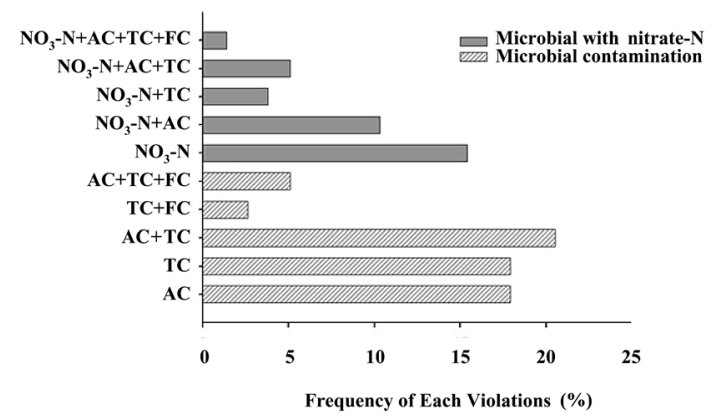

Fig. 1. Histogram of each violations occurrence. AC: Aerobic plate count, TC: Total coliforms, FC: Fecal coliforms.

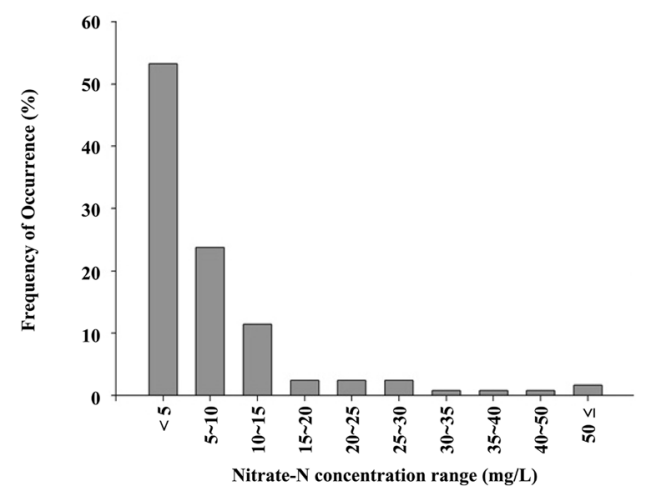

Fig. 2. Frequency distribution of nitrate-N content in groundwater samples. 

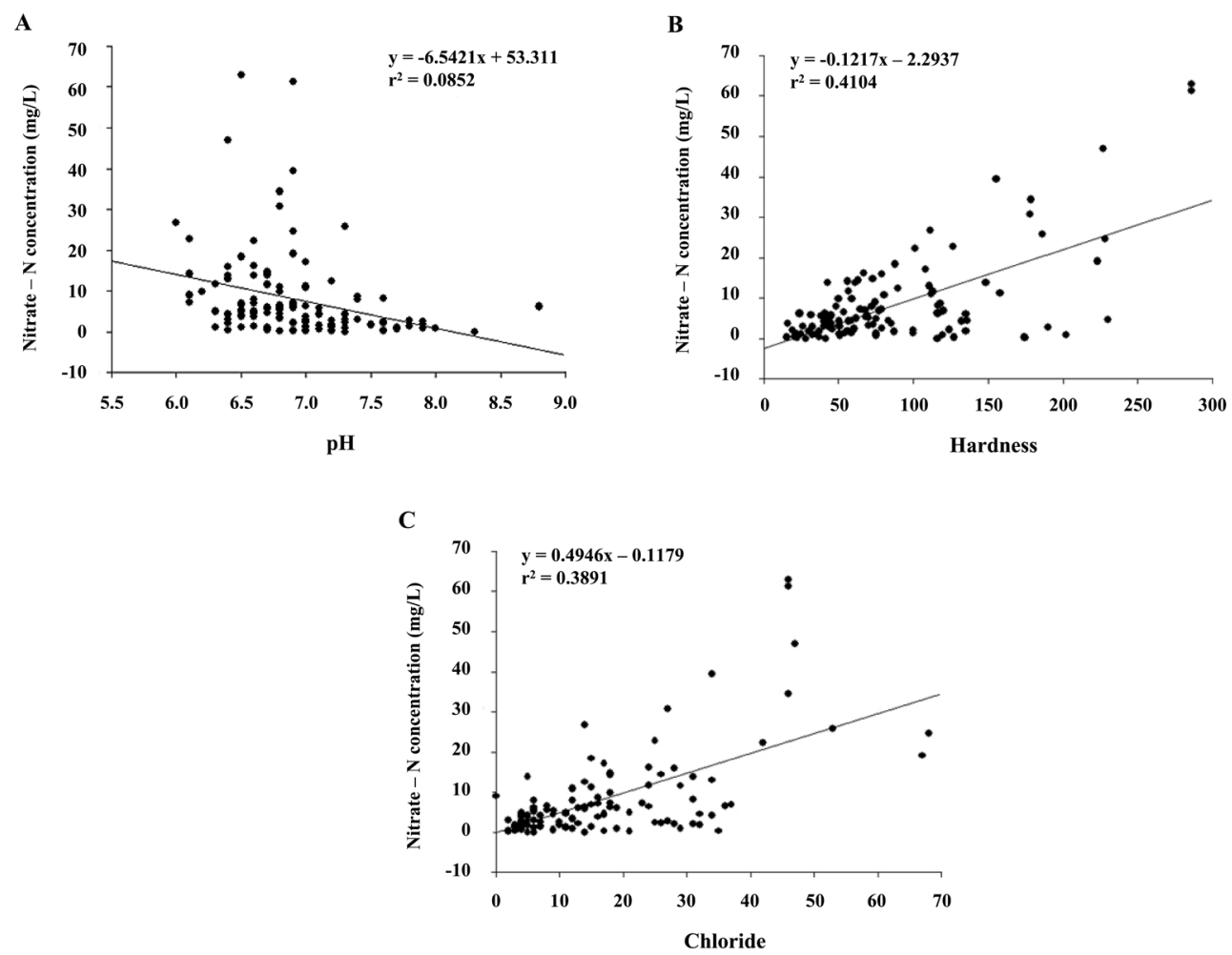

Fig. 3. Relationships of nitrate- $\mathrm{N}$ concentration with $\mathrm{pH}(\mathrm{A})$, hardness $(\mathrm{B})$ and chloride $(\mathrm{C})$ in groundwater.

연과 증발잔류물이었다. 증발잔류물의 경우 3 개의 샘플 에서 기준치 $500 \mathrm{mg} / \mathrm{L}$ 를 초과하였으며 그 수치는 각각 $555 \mathrm{mg} / \mathrm{L}, 730 \mathrm{mg} / \mathrm{L}, 671 \mathrm{mg} / \mathrm{L}$ 였다. 특히 아연이 검출 된 한 개의 샘플에서는 아연의 농도가 기준치인 $3 \mathrm{mg} / \mathrm{L}$ 보다 약 10 배 이상 높은 $32 \mathrm{mg} / \mathrm{L}$ 를 보였다.

질산성 질소 범위 $0 \sim 10 \mathrm{mg} / \mathrm{L}$ 사이에 123 개 샘플 중 95개가 해당되었으며 $10 \sim 20 \mathrm{mg} / \mathrm{L}$ 범위에는 17 개의 농 장이 포함되어 생활용수 기준을 적용했을 경우 약 $91 \%$ 의 농장 지하수가 용도에 적합하였고 먹는물 기준 적용 시에는 28 개 농장의 지하수가 질산성 질소 초과로 인해 부적합한 것으로 분류되었다(Fig. 2).

시료의 $\mathrm{pH}$ 와 경도에 따른 질산성 질소의 농도를 살 펴본 결과 지하수의 $\mathrm{pH}$ 와 질산성 질소의 농도는 연관 성이 없었으나 물의 경도는 높을수록 질산성 질소의 농 도도 높게 나타났으며 염소이온은 농도도 질산성 질소 의 농도와 미약한 상관관계가 있는 것으로 나타났다 (Fig. 3).

\section{고 찰}

본 조사연구는 가축음용수의 기준이 없는 우리나라에
서 자가용 가축음용수의 오염 현황을 파악해 보기 위해 가축사육단계 $\mathrm{HACCP}$ 지정을 준비 중인 농가의 지하수 를 대상으로 실시되었다. 우리나라에는 가축의 음용수 에 대한 수질 기준이 없고 실제로 농가에서 자체 개발 한 지하수를 식수로 사용하는 곳도 있기 때문에 먹는물 수질기준 및 검사등에 관한 규칙에 따라 46개 항목을 검사하였다.

먹는물 수질의 지표 미생물 결과를 보면 분원의 오염 가능성을 시사하는 분원성 대장균군이 검출된 시료는 전체 시료의 약 $5.7 \%$ 를 차지하였고, 총대장균군이 검출 되어 사람이 먹는 물로는 부적합 판정을 받은 시료가 총 44개로 약 $35.8 \%$ 를 차지하였다. 분원성 대장균군과는 달 리 총대장균군은 물이 분원에 오염되었음을 나타내는 지표는 아니나 오랫동안 먹는물 수질의 기준으로 이용 되어왔으며, 총대장균군의 검출은 물의 오염 또는 영양 소 초과 등으로 설명된다 [12]. 그러나 최근의 연구들에 따르면 물에서 총대장균군과 분원성대장균과 같은 지표 세균군의 검출은 Salmonella, Shigella, Vibrio, Clostridium, Legionella, Campylobacter, Aeromonas, Goardia, Cryptosporidium 등과 같이 사람과 동물에게 질병을 일 으킬 수 있는 병원성 미생물이 물에 오염되어 있을 수 
있음을 의미한다고 한다 $[12,13]$.

미생물학적 오염 이외에 질산성 질소 단일 항목에 의 한 부적합이 전체 시료의 $12.2 \%$ 를 차지하였고, 미생물 오염과 함께 질산성 질소가 부적합 검출된 시료는 전체 의 $22.8 \%$ 를 차지하였다. 지하수의 질산성질소 농도에 영향을 주는 인자로 관정의 깊이, $\mathrm{pH}$, 질소비료를 사용 하는 작물재배여부, 가축사육여부 등을 들 수 있다. 이 들 인자와 지하수 내 질산성질소의 농도 간의 상관관계 를 분석한 연구들에 따르면 작물의 종류, 관정의 깊이, 물의 $\mathrm{pH}$, 전기전도도 $(\mathrm{EC})$ 는 질산성 질소 농도와 통계학 적으로 유의한 상관관계가 있다고 한다 $[10,16,19]$. 본 연구에서 물의 $\mathrm{pH}$, 경도와 질산성질소 농도 간의 회귀 분석 결과, 경도가 높을수록 질산성질소의 농도도 높게 나타나는 것으로 나타났다. 이는 지하수의 화학적 성상 에 따라 질산성질소의 용해도가 달라짐을 의미하며 지 역적 지질분포의 차이에 따라 지하수 오염의 원인이나 실태가 다를 수 있음을 나타낸다. 질산염(nitrate)은 그 자체만으로는 독성이 크지 않지만 소 등의 초식동물은 사료로부터 질산염을 섭취하는 비중이 높기 때문에 National Research Council에서 1974년 발간된 자료를 보 면 가축 음용수에서 질산성 질소의 안전한 기준을 10 $\mathrm{mg} / \mathrm{L}$ 이하로 정해 놓고 있다 $[5,9,26] . \mathrm{NRC}$ 자료에 따 르면 질산성질소 수치가 $10 \sim 20 \mathrm{mg} / \mathrm{L}$ 이면 질산염이 적 은 사료와 함께 섭취시 안전하며 $20-40 \mathrm{mg} / \mathrm{L}$ 이면 장기 간 음용 시 위해할 수 있다고 명시하고 있다. 40 100 $\mathrm{mg} / \mathrm{L}$ 에서는 동물이 위험할 수 있으며 죽을 수도 있다 고 한다 $[5,14,16]$. 실제로 아질산염 중독은 질산염을 통해 단백질을 합성해내는 소와 같은 반추수 보다 사람 과 어린 가축에 있어 심각한 문제를 일으킨다. 아질산염 은 혈관으로 들어가서 헤모글로빈(hemoglobin)과 작용 하여 methemoglobin을 형성한다. Methemoglobin은 조직 으로의 산소 운반을 저지하게 되며 호흡곤란을 일으키 게 된다 $[10,16]$. 또한 질산성 질소에 의한 만성적인 영 향에 관한 역학적 연구의 결과에 따르면 질산성 질소를 장기간 음용했을 때 갑상선의 비대부터 15 가지 종류의 암이 발생 할 수 있으며 선천성 기형도 유발할 수 있다 고 보고하였다 [6]. 또한 Payne [19]의 연구에 따르면 오 염된 물을 통한 질산염의 섭취가 증가하면 위암의 발생 률도 증가한다고 한다.

그 외에 아연의 농도가 기준치인 $3 \mathrm{mg} / \mathrm{L}$ 보다 약 10.7 배 높은 수치인 $32 \mathrm{mg} / \mathrm{L}$ 로 나타났다. 아연은 필수 미량 원소로 최근에 들어 $\mathrm{DNA}, \mathrm{RNA}$, 단백질 생성에 관여하 고 면역력에도 영향을 미치는 등 그 기능의 범위가 넓 어 독성보다는 섭취 결핍에 초점이 맞춰져 있다. 그러나 물에서 기준치 이상의 아연이 검출되는 것은 아연으로 도금된 파이프 및 아연이 포함된 배관재의 부식에 의하
여 오염되었을 가능성이 있고 고농도의 아연은 만성중 독을 일으킬 수 있다. 동물에 있어서 아연이 많이 포함 된 경우 물은 불쾌한 맛을 유발하여 물 섭취량이 저하 를 유발하며 이로 인해 생산성에 영향을 미칠 수 있다. 이 뿐만 아니라 대부분의 가축의 경우 하루에 $2,000 \mathrm{ppm}$ 이상의 아연을 섭취할 경우 만성아연중독을 일으킬 수 있다고 한다 $[17,18]$. 우유생산량이 일일평균 $35 \mathrm{~kg}$ 인 체중 $650 \mathrm{~kg}$ 젖소인 경우 약 $101.83 \mathrm{~kg}$ 의 물을 자유음용 하게 되는데 $[1,8]$, 이 경우 매일 $3,200 \mathrm{ppm}$ 이상의 아 연을 섭취하게 되므로 만성중독을 일으킬 수 있다. 섭취 된 아연은 근육에 잔류될 수 있으며 이를 섭취한 사람 에게도 영향을 미칠 수 있다 $[4,28]$. 그러나 우리나라 뿐 아니라 세계적으로도 축산물에서 납, 카드뮴을 제외 한 다른 중금속에 대한 잔류기준은 정해진 바가 없어 무 방비 상태로 노출되고 있다 [3]. 그러므로 보다 광범위 한 역학 조사연구가 수행될 필요성이 있을 것으로 판단 된다.

본 조사에서는 다행히 다이아지논, 파리티온등과 같 은 유기인제 농약과 휘발성 오염물질과 같은 벤젠, 톨루 엔, 크실렌 등은 검출되지 않았다. 그러나 채수기간과 계 절적인 특성 등을 감안한다면 인위적 오염원에 의한 오 염도 발생할 가능성이 있을 것으로 추정된다.

본 연구는 사육단계 $\mathrm{HACCP}$ 지정을 준비하는 농가에 서 가축음용수로 사용하는 자체 개발 지하수를 대상으 로 하였다. 자가용 지하수를 개발하여 급수용으로 사용 하는 축산농가의 경우, $\mathrm{HACCP}$ 을 준비하거나 그렇게 않 은 농가들에 있어서의 차이점이 없어 본 연구결과가 국 내 소사육농가에서 사용하는 자가용 지하수질을 가늠하 는 척도로써 대표성을 가질 수 있을 것으로 생각된다. 현재 사육단계 $\mathrm{HACCP}$ 지정을 위해서는 환경부령 제 362 호 지하수 수질보전 등에 관한 규칙의 생활용수 기 준 중 15 개 항목(벤젠, 톨루엔, 에틸벤젠, 크실렌 제외) 을 만족시키면 되지만, 가축음용수 기준이 없기 때문에 부적합의 결과가 나와도 적절한 제재나 개선조치가 없 는 실정이다.

$\mathrm{HACCP}$ 의 궁극적인 목적은 사람이 축산물을 소비하 는데 있어 각종의 위해요소로부터 안전해야 한다는 것 이다. 그러므로 그 축산물의 오염을 검사하는데 앞서 생 산 단계에서의 감시가 필요하다. 미국, 일본, 유럽연합 등 어느 곳에도 법적으로 정해진 가축음용수 기준은 없 다. 그러나 미국의 경우 cattle, dairy cow, poultry 등으로 축종을 나누고 가축음용수에 대해 염도, 경도, 질산성질 소, 황산이온, $\mathrm{pH}$, 각종 미량원소, 총대장균군에 대한 기 준을 권고사항으로 두고 있으며 대학을 중심으로 가축 음용수 오염에 대한 조사연구 결과가 지속적으로 발표 되고 있다. 
우리나라의 가축사육농가는 대부분 과수원과 경작지 인근에 위치하고 있어 퇴비로 사용된 가축분뇨 및 제초 제, 살충제 등과 같은 오염원에 지속적으로 노출되어 있 다. 이뿐만 아니라 오래되어 부식된 중금속 도금의 급수 배관을 사용하고 있는 농가도 많다. 이러한 환경적 요인 과 함께 축사사육방식으로 지속적으로 오염된 물을 섭 취할 가능성으로 높으며, 일부 오염원의 경우, 축산물에 축적될 수도 있으므로 철저한 감시가 필요하다. 따라서 이와 같은 국내 가축사육농가의 실정을 반영하고, 안전 한 축산식품을 생산하기 위한 최소한의 가축 음용수 기 준을 정립하고 이를 토대로 한 지속적인 가축음용수질 의 감시가 필요할 것으로 사려 된다.

\section{결 론}

본 연구는 소사육농가에서 자체개발하여 가축 음용수 로 쓰고 있는 지하수의 오염실태를 파악하여 가축 음용 수의 기준을 정립하기 위한 기초 자료조사로써 경상남 도와 제주도를 제외한 소 사육농가 123 곳을 대상으로 하 여 환경부령 제 377 조 먹는물 수질기준 및 검사등에 관 한 규칙에 따라 46개 항목을 검사하였다. 검사결과 $63.4 \%(\mathrm{n}=78)$ 의 지하수가 먹는물 기준에 미달하였고 그 원인물질은 질산성질소와 미생물학적 오염, 아연, 증발 잔류물 등이었다. 질산성질소의 경우 $10 \mathrm{mg} / \mathrm{L}$ 를 초과한 경우 음용수로 부적합판정을 받게 되는데 123 개 시료 중 28 개가 해당되었다. 음용수로 부적합 판정을 받은 시료 78개 모두는 일반세균, 총대장균, 분원성 세균에 오염된 시료들로써 특히 7 개의 시료는 분원성 세균이 검출되어 분변에 의한 오염이 있음을 알 수 있었다. 그 외에 한 시 료에서 축산물에 축적될 수 있는 아연이 기준치 $3 \mathrm{mg} / \mathrm{L}$ 의 약 10 배 이상인 $32 \mathrm{mg} / \mathrm{L}$ 가 검출되었으며 이는 아연 으로 도금된 배수관의 부식으로 인한 것으로 판단된다. 대부분의 소사육농가가 경작지에 인접해있기 때문에 질 산성질소가 기준치 초과 검출된 시료의 경우, 경작지와 소사육농가 지하수 오염간의 상관관계를 밝히는 추가적 인 연구가 필요하며 오래된 급수배관을 사용하는 농장 의 경우 축산물로의 축적을 배제할 수 없으므로 지속적 인 감시가 요구된다. 위의 결과를 통해 추정하건데 가축 의 건강 및 가축 생산물의 안전성 확보를 위해 축종별 적합한 음용수 기준 설정이 필요하며 이를 통한 지속적 인 가축음용수질 관리가 필요할 것으로 판단된다.

\section{감사의 글}

이 논문은 2010년 건국대학교 학술진흥연구비 지원에 의한 논문임.

\section{참고문헌}

1. 농림부, 농촌진흥청 축산기술연구소. 한국사양표준(젖 소). pp. 115 121, 농촌진흥청 축산기술연구소, 수원, 2002.

2. 방상원, 정재현. 우리나라와 선진국간의 지하수 수질 기준에 관한 고찰. 환경정책연구 $2005,4,57-82$.

3. 식품의약품안전청. 식품공전. pp. 별표6, 6-1 6-11, 식 품의약품안전청, 청원, 2008.

4. Cabrera MC, Ramos A, Saadoun A, Brito G. Selenium, copper, zinc, iron and manganese content of seven meat cuts from Hereford and Braford steers fed pasture in Uruguay. Meat Sci 2010, 84, 518-528.

5. Committee on Minerals and Toxic Substances in Diets and Water for Animals, National Research Council. Mineral Tolerance of Animals. 2nd ed. National Academy Press, Washington, 2005.

6. Forman D, Al-Dabbagh S, Doll R. Nitrates, nitrites and gastric cancer in Great Britain. Nature 1985, 313, 620-625.

7. Graf GC, Holdaway CW. A comparison of "hard" and commercially softened water in the ration of lactating dairy cows. J Dairy Sci 1952, 35, 998-1000.

8. Holter JB, Urban WE Jr. Water partitioning and intake prediction in dry and lactating holstein cows. J Dairy Sci 1992, 75, 1472-1479.

9. Hubbard RK, Newton GL, Hill GM. Water quality and the grazing animal. J Anim Sci 2004, 82 (E-Suppl), E255-263.

10. Khublarian MG. Chemical substance transport in soils and its effect on groundwater quality. Environ Health Perspect 1989, 83, 31-37.

11. Kundu MC, Mandal B, Hazra GC. Nitrate and fluoride contamination in groundwater of an intensively managed agroecosystem: a functional relationship. Sci Total Environ 2009, 407, 2771-2782.

12. Liu A, Ming J, Ankumah RO. Nitrate contamination in private wells in rural Alabama, United States. Sci Total Environ 2005, 346, 112-120.

13. Lye DJ. Health risks associated with consumption of untreated water from household roof catchment systems. J Am Water Resour Assoc 2002, 38, 13011306.

14. Meera V, Mansoor Ahammed M. Water quality of rooftop rainwater harvesting systems: a review. J Water Supply: Res Technol 2006, 55, 257-268.

15. Murphy MR. Water metabolism of dairy cattle. J Dairy Sci 1992, 75, 326-333. 
16. Ndengerio-Ndossi JP, Cram G. Pesticide residues in Table-ready foods in Tanzania. Int J Environ Health Res 2005, 15, 143-149.

17. Osweiler GD. Toxicology. 1st ed. pp. 204-205, WileyBlackwell, Philadelphia, 1996.

18. Pardío VT, Waliszewski KN, Landín LA, Bautista RG. Organochlorine pesticide residues in cow's milk from a tropical region of Mexico. Food Addit Contam 2003, 20, 259-269.

19. Payne MR. Farm waste and nitrate pollution. In: Jones JG (ed.). Agriculture and the Environment. pp. 63-73, Ellis Horwood, New York, 1993.

20. Reddy AG, Niranjan Kumar K, Subba Rao D, Sambashiva Rao S. Assessment of nitrate contamination due to groundwater pollution in north eastern part of Anantapur district, A.P. India. Environ Monit Assess 2009, 148, 463-476.

21. Salas JH, González MM, Noa M, Pérez NA, Díaz G, Gutiérrez R, Zazueta H, Osuna I. Organophosphorus pesticide residues in Mexican commercial pasteurized milk. J Agric Food Chem 2003, 51, 44684471.

22. Smith RM, Leach RM, Muller LD, Griel LC Jr, Baker DE. Effects of long-term dietary cadmium chloride on tissue, milk, and urine mineral concentrations of lactating dairy cows. J Anim Sci 1991, 69,
4088-4096.

23. Solomon R, Miron J, Ben-Ghedalia D, Zomberg Z. Performance of high producing dairy cows offered drinking water of high and low salinity in the Arava desert. J Dairy Sci 1995, 78, 620-624.

24. Steiger Burgos M, Senn M, Sutter F, Kreuzer M, Langhans W. Effect of water restriction on feeding and metabolism in dairy cows. Am J Physiol Regul Integr Comp Physiol 2001, 280, R418-427.

25. Subcommittee on Beef Cattle Nutrition, Committee on Animal Nutrition, Board on Agriculture, National Research Council. Nutrient Requirements of Beef Cattle. 7th ed. pp. 80-81, National Academy Press, Washington, 1996.

26. Subcommittee on Dairy Cattle Nutrition, Committee on Animal Nutrition, Board on Agriculture and Natural Resources, National Research Council. Nutrient Requirements of Dairy Cattle. 7th ed. pp. 178183, National Academy Press, Washington, 2001.

27. Van Leeuwen FXR. Safe drinking water: the toxicologist's approach. Food Chem Toxicol 2000, 38 (1 Suppl), S51-58.

28. Willett LB, O'Donnell AF, Durst HI, Kurz MM. Mechanisms of movement of organochlorine pesticides from soils to cows via forages. J Dairy Sci 1993, 76, 1635-1644. 